\title{
Measurement of the Domestic Money Stock*
}

\author{
by ALBERT E. BURGER and ANATOL BALBACH
}

\begin{abstract}
Under certain circumstances, the current definition of money does not reflect international capital flows that change the money holdings of U.S. residents. This article analyzes those circumstances in which this can occur and presents a domestic money stock series that captures these influences. It may be that total spending responds not only to changes in the grouth of money, but also to changes in the proportion held by U.S. residents. Therefore, it is hoped that the data provided will generate studies which compare the relationship between total spending and changes in the domestio money stock, as well as the relative efficiency with which domestic money can be controlled by the monetary authorities.
\end{abstract}

M

ASSIVE dollar outllows in 1969, 1970 and 1971 have focused renewed attention on the impact of international financial transactions on the money stock, and therefore on total spending in the United States. For example, in a review of financial developments in the third quarter of 1971, the Federal Reserve stated:

It seems likely that the sharp slowing of $M_{1}$ growth in August [1971] was in large part attributable to the heavy outflow of dollars into foreign exchange markets. ${ }^{1}$

An airplane being loaded with U.S. dollars and flying off to foreign lands is a common interpretation of dollar outflows. This is an incorrect view since, given the current inconvertibility of the U.S. dollar into gold or other reserve assets and the use of the U.S. dollar as an international reserve currency, an outflow of dollars simply means that demand deposits of U.S. residents are declining and deposits of foreign residents at U.S. banks are increasing. It will be shown that in certain important cases these transactions have no effect on the money stock as it is currently defined.

It is reasonable to expect that foreign owners of deposits at U.S. banks are subject to different variables affecting their portfolio adjustments than are domestic depositors. This is particularly true when one considers that the dollar is used as an international reserve currency. Therefore, for purposes of predicting economic activity and controlling such activity, it becomes important to measure not only the changes in the money stock but also its composition.

This article first shows how international transactions affect both the current measure of the money

\footnotetext{
*In the early stages of preparation for this article, Mr. Clark Warburton made available to the authors his work on constructing a private domestic money stock series. Also, the authors benefited from comments by Professor Michele Fratianni. The authors asstme sole responsibility for the analysis and conclusion of the article.

1"Financial Developments in the Third Quarter of 1971," Federal Reserve Bulletin (November 1971), p. 872.
}

stock and an altemative measure, which we will call the domestic money stock. Secondly, a brief history and explanation of the derivation of the current measure of the money stock is presented. Third, series on foreign demand and time deposits are constructed and are then used to derive a domestic money stock series. These series are presented in the appendix.

\section{Impact of International Transactions on Current Money Stock}

The money stock $\left(M_{1}\right)$, as currently defined, includes (in addition to domestic demand deposits): U.S. commercial bank demand deposits due to foreign individuals, partnerships, corporations, commercial banks, central banks, and international institutions; deposits of U.S. branches of foreign banks, U.S. agencies of foreign banks, and Edge Act subsidiaries of domestic banks; and foreign deposits at the Federal Reserve. The more broadly defined money stock $\left(\mathrm{M}_{2}\right)$ includes, in addition, domestic and foreign time deposits except for negotiable time certificates of deposit of $\$ 100,000$ or more.

In order to examine how foreign transactions affect the U.S. money stock $\left(M_{1}\right.$ and $\left.M_{2}\right)$, as currently defined, this section discusses and presents the balance sheet effects of these transactions in simple T-account form. Exhibit I gives a general view of the various transactions and their effects on the money stock, as currently defined, and on a domestic money stock series. The examples represent transactions associated with an outlow of dollars from the United States. By reversing signs, the impact of inflows can be analyzed. It is assumed that there is no convertibility into gold and other reserve assets and that exchange stabilization agreements have produced a situation where dollars are used as a source of international liquidity and as an intervention currency.

Suppose that U.S. imports increase relative to exports or that U.S. residents increase their purchases 
Exhibit I

\section{Impact of Dollar Outflows on U.S. Monetary Accounts}

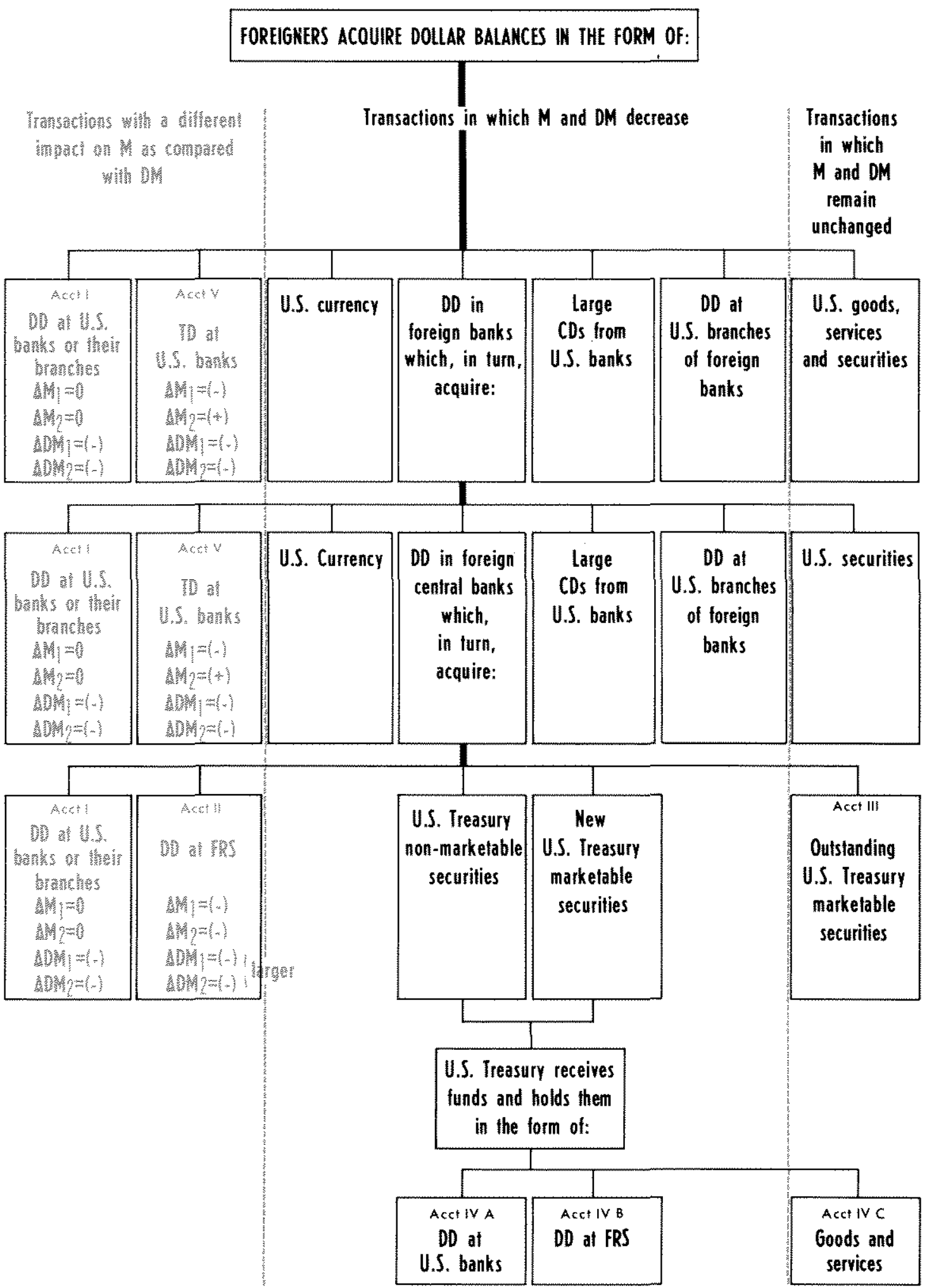


of foreign assets, securities, or foreign deposits. In either case, foreign sellers find themselves holding more U.S. dollars than before. To determine the effect on the U.S. money stock we must answer the question: What do foreigners do with the increased dollar balances?

Foreigners have several alternatives. They can: (1) increase purchases of U.S. goods and services and securities: (2) increase their deposits at U.S. banks, or at foreign branches of U.S. banks; (3) increase their deposits at banks in their own country; (4) increase their deposits at branches of foreign banks in the United States; and (5) increase their holdings of U.S. currency. In the following discussion we will consider only the first four alternatives.

In the first case, there is no net change in the U.S. money stock because dollar balances are reinjected directly back into the hands of U.S. residents. In the second case, demand deposits of U.S. residents decrease, but demand deposits of foreigners at U.S. banks (also part of the money stock) increase, as shown in Account I (also see Exhibit I).

Account I

Foreigners Increase Demand Deposits at U.S. Banks

\section{U.S. Bonks}

(unchanged) Reserves

(-) Demand Deposits (U.S.)

(+) Demand Deposits (Foreign)

In the case where foreigners deposit dollars in foreign banks, a further question must be asked: What do the foreign commercial banks do with the dollar deposits? The foreign banks may increase their dollar deposits at their correspondent banks in the United States, or they may sell these dollars to their central bank. In the first situation, demand deposits of U.S. residents at U.S. banks decrease and demand deposits of foreign banks at U.S. banks (which are included in the U.S. money stock) increase. There is no net change in the money stock. The final T-account results would be the same as illustrated in Account $I$. If foreigners or foreign banks increase their demand deposits at U.S. branches of foreign banks, money stock, as currently defined, will decrease.

If foreign banks sell dollars to their central bank, then the question arises: What does the central bank do with the dollars? The foreign central bank may: (1) increase its dollar deposits at U.S. commercial banks; (2) increase its dollar balances at the Federal Reserve; (3) increase its dollar balances at the Federal Reserve and instruct the Federal Reserve to buy
U.S. govermment securities for its account; or (4) buy special nonmarketable securities directly from the U.S. Treasury. Since deposits of foreign central banks at U.S. conmercial banks are included in the money stock, then (1) would result in no net change in the money stock, and the final $\mathrm{T}$-account effect would be the same as illustrated in Account I.

If foreign central banks hold increased deposits at the Federal Reserve, the initial effect is no change in the money stock (since deposits of foreigners at the Federal Reserve are part of the current definition of $\mathrm{M}_{1}$ and $\mathrm{M}_{2}$ ). The initial effect of this transaction is illustrated in Account II. Such a transaction, however, decreases the reserve base of U.S. banks, and as a result, the money stock decreases over time, if not offset by other actions.

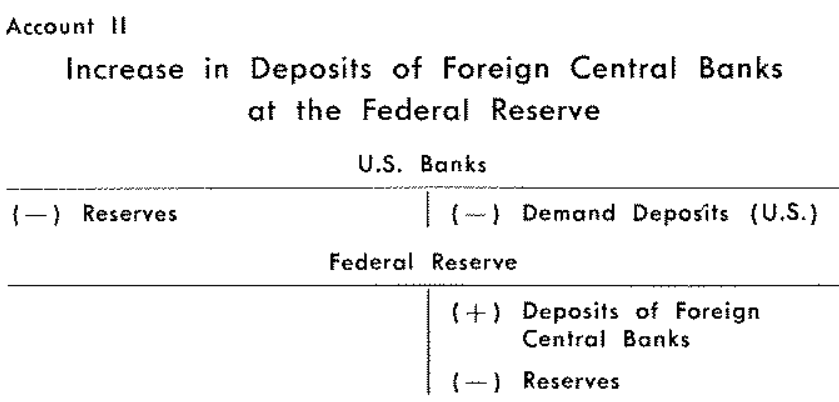

If, instead of holding increased dollar balances at the Federal Reserve, the foreign central bank instructs the Federal Reserve Bank of New York to buy securities for the foreign central bank's account, then there is no net change in the money stock or the reserve base. Account III illustrates this result, where the items above the dotted line show the first stage of the transaction, comparable to Account II, and the items below the dotted line show the effect of the Federal Reserve purchase of securities for foreign account.

Account III

Increase in Deposits of Foreign Central Banks at the Federal Reserve and the Federal Reserve Purchases Securities for Foreign Account

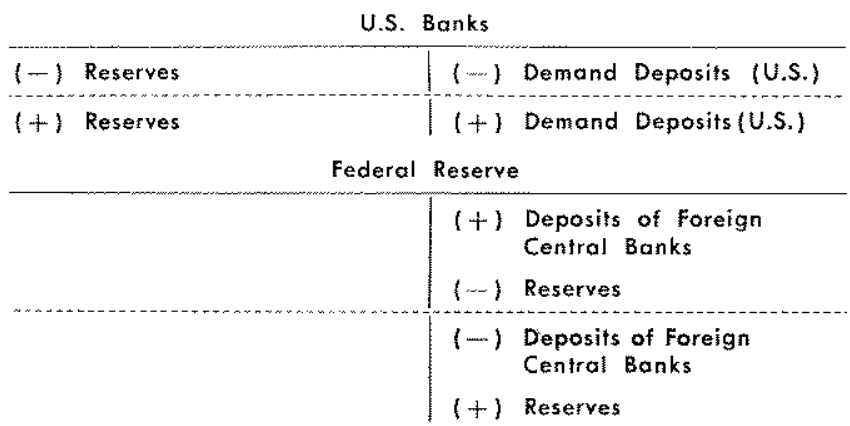

Another atternative use of dollar balances that has become available to foreign central banks in recent 
years is the purchase of nonmarketable securities directly from the U.S. Treasury. To analyze the effect of this action on the money stock one additional question must be answered: What does the Treasury do with the proceeds from the sale of these securities? The Treasury has three options: (1) increase Treasury deposits at commercial banks; (2) increase Treasury deposits at the Federal Reserve; or (3) spend the proceeds. If the Treasury uses either options (1) or (2) the money stock decreases (since Treasury deposits are not included in the current money stock). The result for the case where the Treasury increases its deposits at U.S. commercial banks is illustrated in Account IV.A, and the case where Treasury deposits at the Federal Reserve are increased is shown in Account IV-B. When Treasury deposits at the Federal Reserve are increased, this also results in a decrease in the reserce base. Hence, option (2) has a potentially greater contractionary influence on the money stock than option (1). If the Treasury spends the proceeds, the money stock is unchanged, as illustrated in Account IV-C. The same results occur when foreign official agencies buy newly issued marketable securities from the Treasury.

Account IV

FOREIGN CENTRAL BANK BUYS NONMARKETABLE OR NEWLY ISSUED MARKETABLE SECURITIES FROM THE TREASURY

A. Treasury Increases Its Deposits at Commercial Banks

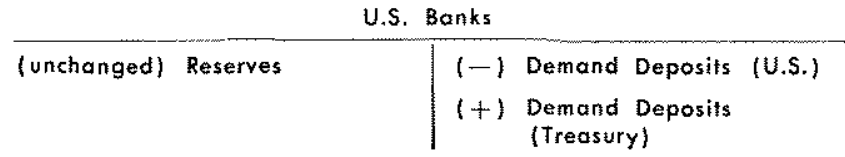

Treasury

\begin{tabular}{l|l}
\hline $1+1$ Demand Deposits & $(1)$ Securities
\end{tabular}

B. Treasury Increases fits Deposits at the Federal Reserve

$\frac{\text { U.S. Bonks }}{(-1) \text { Reserves }} \frac{(-) \text { Demand Deposits (U.S.) }}{\text { Federal Reserve }}$

$\frac{\text { Federal Reserve }}{(1+1) \begin{array}{l}\text { Demand Deposits } \\ \text { (Treasury) } \\ 1-1 \text { Reserves }\end{array}}$

\begin{tabular}{l|c} 
Treasury \\
\hline $\begin{array}{c}1+1 \text { Deposits at } \\
\text { Federat Reserve }\end{array}$ & $(+1$ Securities
\end{tabular}

\section{Treasury Spends the Proceeds}

U.S. Banks

(unchanged) Reserves

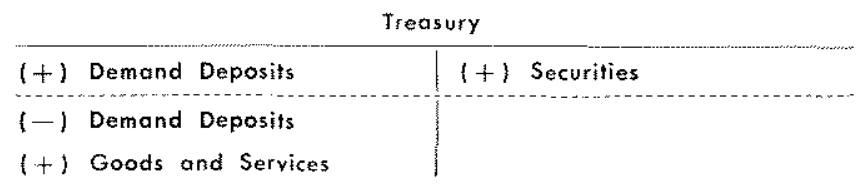

If foreign holdings of dollars increase there is one additional use of these dollars that has not yet been discussed. Foreigners may increase their holdings of time deposits in U.S. banks. For example, a decrease in demand deposits of U.S. residents may reappear as an increase in time deposits of foreign individuals or commercial banks. Since $\mathrm{M}_{2}$ excludes large negotiable time certificates of deposits (CDs), the effect on $\mathrm{M}_{2}$ depends upon whether foreigners increase their holdings of large CDs or their holdings of other time deposits.

First, assume as in the previous cases, there is an outtlow of dollar deposits that appears on the balance sheets of U.S. banks as a decrease in demand deposits of U.S. residents. Now let us suppose foreigners increase their holdings of other time deposits (net time deposits rise). In this case, initially required reserves are decreased and in the ensuing adjustment process, $M_{1}$ decreases but $M_{2}$ rises (total demand plus net time deposits rise, but demand deposits alone decrease). This result is illustrated in Account V. However, if foreigners use these dollar claims to increase their holdings of large CDs newly issued by U.S. banks, the result of these transactions would be a decrease in $M_{1}$ and $M_{2}$ (because large $C D$ s are not included in either measure).

Account $V$

$$
\begin{gathered}
\text { Foreigners Increase Holdings } \\
\text { of Other Time Deposits }
\end{gathered}
$$

\begin{tabular}{l|l} 
U.S. Banks \\
\hline (unchanged) Reserves & $\begin{array}{l}(-) \text { Demand Deposits (U.S.) } \\
(+) \text { Net Time Deposits } \\
\text { (Foreign) }\end{array}$
\end{tabular}

As illustrated by the above examples, the current definition of the money stock $\left(M_{1}\right)$ does not reflect dollar outllows when foreigners (either private or official) increase their demand deposits at U.S. commercial banks. These transactions must be viewed as neutral in terms of their impact on the U.S. economy through money stock, as currently defined. The current definition of $\mathrm{M}_{1}$ does not reflect the full effect of an increase in foreign deposits at the Federal Reserve on money balances of U.S. residents. Also, an outflow of dollars from demand deposits that reappears as an increase in foreign holdings of other time deposits results in an increase in $M_{2}$, as currently defined; this reflects both the increase in foreign time deposits and 
the expansionary effect of the reduction in required reserves caused by the switch from demand to time deposits.

\section{Impact of International Transactions on the Domestic Money Stock}

A domestic money stock (DM $)$ should reflect the effect of dollar outhlows on money holdings of U.S. residents. Excluding foreign deposits that offset changes in holdings of money balances by U.S. residents from the money stock results in substantial differences in the effects of some foreign transactions on the money stock. ${ }^{2}$ For example, in the case illustrated in Account I, where there was an outflow of dollars that appeared as a decrease in demand deposits of U.S. residents and an increase in foreign demand deposits of U.S. banks, the domestic money stock $\left(\mathrm{DM}_{1}\right.$ and $\mathrm{DM}_{2}$ ) would decrease, whereas the money stock, as currently defined, would remain unchanged. If foreign deposits at the Federal Reserve rise, then the domestic money stock would decrease by more than the current money stock. $\mathrm{DM}_{1}$ would decrease by the amotmt of the increase in foreign deposits at the Federal Reserve as well as by the effect of the decrease in the reserve base. When foreign time deposits rise $\mathrm{DM}_{2}$ would decrease, in contrast to the current definition of $\mathrm{M}_{2}$ which would increase. Exhibit I presents alternative forms of dollar holdings by foreigners and the effects of a dollar outflow on the current definition of money as compared to its proposed alternative.

Except in those cases where foreigners reinject money into the U.S economy either through direct purchases of securities or indirectly through Treasury spending, dollar outflows are associated with decreases in the domestic money stock.

\section{Federal Reserve Measurement of the Money Stock}

Since the domestic money stock data are derived from the current Federal Reserve Board estimates of the money stock, it is necessary to present a description of how various components are currently derived and entered into the final concept of the money stock series. ${ }^{3}$

In the construction of the domestic money stock series, we were unable to estimate foreign holdings of U.S. currency because of limitations of the data. Therefore, domestic money stock exchdes foreign deposits only.

The Federal Reserve System did not publish comprehensive estimates of the components of the money stock until the early 1940s. In 1941, the Federal Reserve published Banking
On June 8, 1959, the Federal Reserve System appointed the Ad Hoc Committee on Money Supply Statistics." This committee issued a report on October 8, 1959, entitled Recommendations for Statistics of Money Supply and Member Bank Reserves that formed the basis for the present money stock series published by the Federal Reserve System."

The defintion of money chosen by the Federal Reserve was based on a "means-of-payment" or "mediumof-exchange" concept. "This concept of money did not deny the possible importance of other "liquid assets." However, the System argued that:

Even the most liquid of these other types of assets, however, must generally be converted into money, as defined here, before being used in economic transactions. The amount of nonmonetary financial instruments outstanding is not limited by the supply of reserve funds as is the volume of bank deposits. It is true that reserves are needed to support time deposits in member banks but the amount absorbed in this way is relatively small and is allowed for in the reserve projections before assessing the reserve ac tions needed for monetary purposes. ${ }^{7}$

The Federal Reserve System decided that, for the purposes of monetary policy, "the most useful definition of the money supply covers the total of the

Studies in which estimates appeared for bank deposits and currency, 1890-1940. In 1943, Banking and Monetary Statistics was published, and included were series on currency outside banks and demand deposits adjusted. Until October 1960 , there was no item in the Federal Reserve statistics labeled "money stock," although the components of the money stock appeared in the table "Consolidated Condition Statement for Banks and the Monetary System."

4The Ad Hoc Committee was appointed by the Chairnan of the Research Advisory Committee at the request of the Federal Open Market Committee. Roland Robinson, who at that time was an Adviser for the Division of Research and Stafistics at the Board of Governors, was chosen as Chairman of the Ad Hoc Committee. Other members of the committee included William J. Abbott, Harry Brandt, Robert S. Enzzig and Clarence $W$, Tow.

3in Federal Reserve publications and elsewhere, the term money supply instead of money stock often appears. The data are collected as an average of amounts at points in time, hence a stock concept. Therefore, except in direct quotations, the term money stock rather than money supply will be used.

"There are several major theoretical or "a priori" approaches to the concept of money. One of these is the "medium-ofexchange" oT "means-of-payment" concept of money. "The other is the "liquidity" concept of money. An important dis. tiaction between these two approzches is the emphasis each places on supply and demand conditions for "money." The liquidity concept stresses demand conditions. Money is only one of many assets that economic units may choose to hold in their wealth portfolios. One factor influencing wealth-holders" portfolio decisions is the relative liquidity of various assets. The means-of-payment concept emphasizes the supply conditions for the asset called money. See Milton Friedman and Anna I. Schwartz, Monetary Statisties in the United States: Estimates, Sources, Methods (New York: Columbia University Press, 1970), Chapter 3, especially pp. 136-137.

7 "A New Measure of the Money Supply," Federal Reserve Bulletin (October 1960), p. 1103. 
public's holdings of coin, currency, and demand deposits in banks." Included in the nonbank public were individuals, basiness firms, nonbank financial institutions (such as savings and loan companies), mutual savings banks and life insurance companies, state and local govemments, foreign official and private institutions, and after mite 1962, foreign demand balances at Federal Reserve Banks."

The Federal Reserve System frst began publication of a separate and distinct money stock series in the October 1960 Federal Reserve Bulletin. In the writeup accompanying this section, it was stated:

The amount of money in existence and changes in this amount influence the course of economic devel opments. For this reasor accurate measurement of the money supply and of changes in the supply is of great importance. ...

The Federal Reserve System has primary responsibility for regulating the total volume of money available to meet the public's demands. ${ }^{10}$

Due to the institutional structure of commercial balking and the availability of reported data, several measurement problems remained. The major one of these, that relates to the construction of the domestic money stock series, was an adjustment for cash items in process of collection.

The number assigned to the money stock at any point in time should represent the amount of money that money holders assume they have available to use, not necessarily the amount that bank records show they hold." The difference between bank records and holder records arises because of bank toat, which develops when banks give depositors credits for checks deposited with them before the banks on which the checks were witten have debited the accounts of persons who wrote the checks. The method used by the Federal Reserve to correct for this double counting is to subtract cash items in process of collection (CIPC) from gross demand deposits. ${ }^{12}$

\section{Ibid.}

DDemand deposits that banks in U.S. territories and possessioms held at U.S. commercial barks were also added to the money stock data.

$10^{\prime \prime}$ A New Measure," p. 1102.

${ }^{11 T} \mathrm{~T}$ be in exact conformity with the money stock concept chosen by the Federal Reserve, the measurement of money should be based on records of money holders. Ideally, by checking the actual records of each economic mit, one could deternine at any point in time the anount of currency, coin and demand deposits that the nonbank public assmmes it holds. Becanse of the great practical difficulties involved in such a measurement procedure, an indirect method was chosen. Rather than directly examining the records of each money holder, an approximation was used based on bank records.

twAnother source of double counting, called Federal Reserve float, arises due to delays in clearing and collecting checks

\section{Holusion of Foreign Deposits in the Money Stock}

Prior to 1960, demand deposits adjusted, which were reported in the table "Consolidated Condition Statement for Banks and the Monetary System" in the Federal Reserve Bulletin, included demand deposits due to foreign individuals, partnerships, corporations, govemments and govermment agencies, but excluded demand deposits due to foreign banks and foreign deposits at the Federal Reserve Banks. ${ }^{13}$

In the development of the money stock series in 1960 , demand balances of foreign banks at U.S. commercial banks were included in the money stock. This decision was made jointly with the decision to include demand balances of mutual savings banks at commercial banks. These foreign deposits, which were initally excluded from the money stock by the subtraction of "Interbank Deposits," were added back into the money stock figures in the item "Interbank Demand Deposits of Foreign and Mutual Savings Banks" (see Table I). $1^{14}$

The following justification was given for including foreign bank deposits:

Amounts due to these institutions represent cash available for investment in much the same way as balances of other financial institutions and involve no duplication of funds held by others. ${ }^{15}$

Foreign demand deposits held at Federal Reserve Banks were added to the money stock in August 1962, and included demand balances at Federal Reserve Banks due to foreign governments, central banks and intermational institutions. The addition of these foreign deposits to the money stock was justified on the same basis as the inclusion of deposits due to foreign banks.

through the Federal Reserve System. The misstatement of the money stock arising from this source is not removed by deducting cash items from gross demand deposits. To avoid this bias in the money stock, Federal Reserve Hoat is also deducted from demand deposits to arrive at the demand deposit component of the money stock.

13Demand deposits adjusted were computed by deducting demand balances due to banks, which included foreign banks.

14 Estimates of demand balances due to foreign banks were prepared separately for member and nommember banks. In 1960 , it was estimated that for the period 1947 to date foreign demand balances were in the range of $\$ 1.3-\$ 1.8$ billion. Beginning April 26, 1961, weekly reporting member banks were required to report separate figures for demand balances due to foreign banks. This change permitted more accurate estimation of demand balances due to foreign banks, which had previously been available only from call reports for, at most, four dates a year.

15 "A New Measure," p. 1103. 
[They] may be used for investments or other expenditures in much the same way as foreign demand balances with commercial banks. . . With their addition the daily average series includes all demand deposit and currency liabilities to foreigners. ${ }^{16}$

At that time the Federal Reserve was confident that adding foreign deposits at Federal Reserve Banks had almost no effect on the past money stock data.

Over the 1950-57 period foreign balances at Federal Reserve Banks showed a fairly steady decline. However, estimates indicate that roughly offsetting in creases occurred in foreign balances at commercial banks. Consequently, the estimated total of foreign demand balances was relatively stable and has not shared in the growth of the total money supply since 1947. The addition of foreign balances at Federal Reserve Banks to the demand deposit component has had no observable effect on seasonal factors for this series. ${ }^{17}$

In 1969 and 1970 , certain types of international transactions produced additions to the deposits used to compute the money stock. The August 1969 revision of the money stock data resulted primarily from Eurodollar transactions by commercial banks. These transactions did not involve any double counting of demand deposits held by the public; yet they operated to reduce the demand deposit component of the money stock because the cash items generated by these transactions were deducted from it. Effective July 31, 1969, under a revision of Federal Reserve Regulation $\mathrm{D}_{3}$ the issuing banks were required to include bills payable checks and London checks used in repayment and borrowing of Eurodollars in gross demand deposits as well as in cash items in process of collection.

The major part of the November 1970 money stock revision was precipitated by international transactions involving Edge Act corporations and U.S. agencies and branches of foreign banks. These transactions did not give rise to deposit liabilities at domestic commercial banks to offset the cash items generated. ${ }^{18}$ To correct for this measurement error in the demand dem posit component of the money stock, data were collected from U.S. agencies and branches of foreign banks and from Edge Act corporations, and added to gross member bank demand deposits.

16"Revision of Money Supply Series," Federal Reserve Bulletin (August 1962), p. 944 .

17 Ibid.

1.8 A deposit of an Edge Act corporation or similar institution was treated as an interbank deposit by a U.S bank, and, therefore, was not included in the demand deposit component of money. The cash items generated by these transactions were included in total cash items which are deducted from gross demand deposits (see Table I).
The August 1969 and November 1970 revisions did not generally result in a net addition of a new class of foreign deposits, as had the 1960 and 1962 revisions. In the 1969 and 1970 revisions, certain classes of foreign deposits were added to the data to compute the money stock only to offset the cash items in process of collection that these transactions generated. However, foreign agencies and Edge Act corporations are now treated as part of the commercial banking system for purposes of money stock measurement, and as a result, a small amount of deposits held more or less permanently by their customers were added to the money stock data. ${ }^{10}$

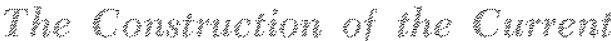 Wowen shock Seres}

The procedure for measuring the money stock is summarized in Table I. ${ }^{20}$ First, the currency component of the money stock is estimated by using 'Treasury data, Federal Reserve data on member bank vault cash and estimates of nonmember bank vault cash. Second, gross member bank demand deposits are computed, based on weekly reports of member banks. Gross demand deposits are then adjusted by deduct ing deposits that are not due to the nonbank public, such as deposits due to the U.S. Government and banks. Third, nonmember bank demand deposits adjusted are estimated using semi-annual benchmark data from call reports and country member bank data. ${ }^{* 1}$ Data from the records of $F$ ederal Reserve Banks is used for foreign deposits at Federal Reserve Banks and Federal Reserve float. Subtracting Federal Reserve float from demand deposits adjusted and adding these foreign deposits yields the demand deposit component of the money stock. $\mathrm{M}_{2}$ is constructed by adding to the money stock $\left(\mathrm{M}_{1}\right)$ commercial bank savings deposits, time deposits, and time certificates

15"Revision of the Money Stock," Federal Reserve Bulletin (December 1970), p. 892.

20 One of the recommendations of the Ad Hoc Committee was that figures for the money stock be based on daily average data. Beginning in the October 1960 Federal Reserve Bulletin, the Federal Reserve began publishing a semi-monthy money stock series based on averages of daily figures extending back to January 1947. The series were presented on an unadjusted and seasonally adjusted basis. Also, a nonseasonally adjusted weekly series was published for 1960 . To the extent that money stock data were used in making policy decisions, the daily average series replaced the lastWednesday and call report data published regularly in the Bulletin. In Jume 1964, the System began publication of monthly average money stock data based on weighted averages of semi-monthly data. In July 1965, the Systern began publishing weekly and monthly seasonally adjusted data computed on a daly average basis and extending back to January 1959.

21 About one-fourth of the demand deposit portion of the money stock is accounted for by nonmember banks. 
10610.1

Wethod of Computing Money Stock $\left(M_{1}\right.$ ond MI)

A. Currency Componenl

less:

Curreng, in Ciculotion

Vault Cash or Conmerial Bantes

B. Denand beposil Component of Menber Eanks

toss

interbano bemardo beposits

US Governent De wonct De po ifs.

1.105:

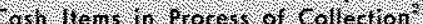

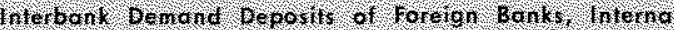
thond Iistifutions and Mufuel Scrings Banks?

C. Denand Deporit Conponent of Nonmember Banks

tross.

Gross Denand beponits

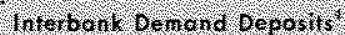

US. Government Demarid De posits

Cosh llens in Process of Collection

b. Demard Depoit Component of Money Stack

16 .

(0) p pus ic

frederol kesterye tiont?

plost

foreigh Deposits will federd Reserve Bonks?

c. Nonior Stodk $M_{1}$

(1) plus 10 )

1.) Money stod $\mathrm{M}_{2}$

r.

Money stodk Mi

sovings Deposits, line beposits Open Account ond I Ire Cerificales of Deposit Exaluding Donestic lrierbank and U.s Goverment Thite Deposits?

tess:

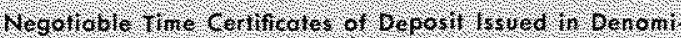
nations of $\$ 100,000$ or More:

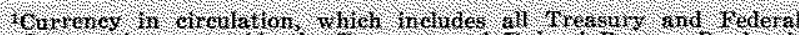

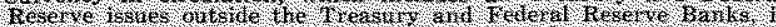

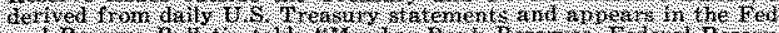

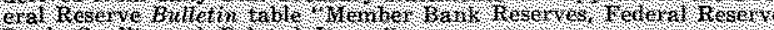

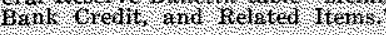

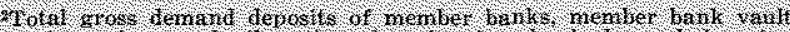

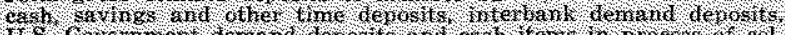

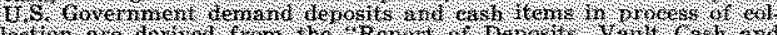
Feder a

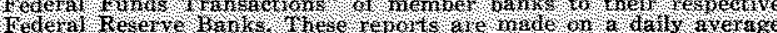
bats of v lle weer

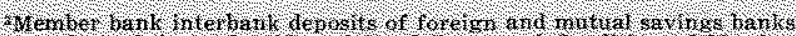

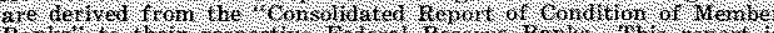

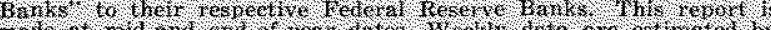

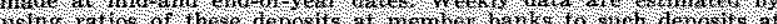
(1) 17250

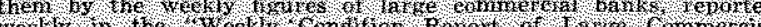
weest

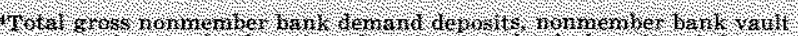

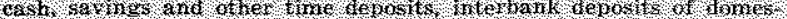

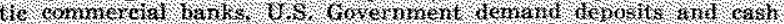

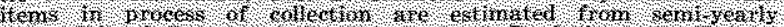

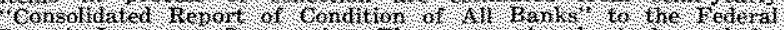

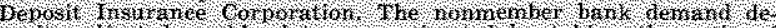

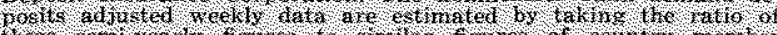

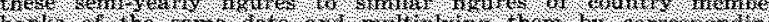

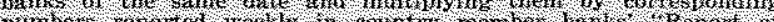

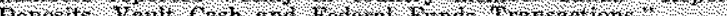

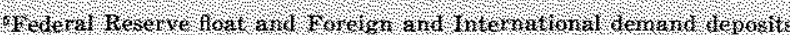

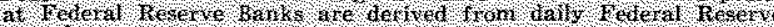
trecorts:

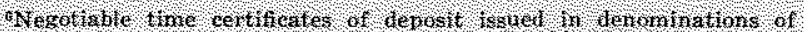

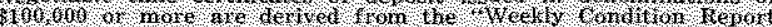

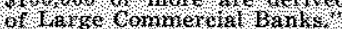

of deposit, exclusive of negotiable time certificates of deposit issued in denominations of $\$ 100,000$ or more by large weekly reporting commercial banks.

\section{The Measurement of Domestic Money Stock}

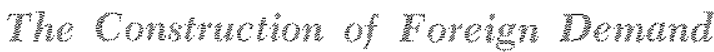 and The Deposis Series}

Demand deposit liabilities of U.S. commercial banks to foreign individuals, partnerships and corporations (IPC deposits) are not reported separately in the weekly "Report of Deposits, Vault Cash and Federal Funds Transactions," but are lumped together with domestic IPC deposits. Therefore, to estimate these foreign deposits, data collected by the Treasury Department were used. These data appear in the Federal Reserve Bulletin table entitled "Short-Tem Liabilities to Foreigners Reported by Banks in the United States, by Type," column headed "Demand Deposits to Other Foreigners."2z

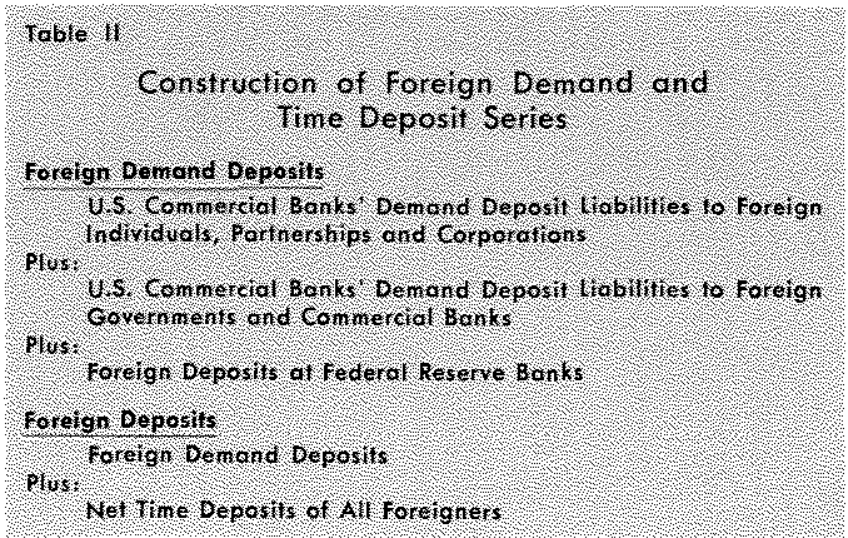

The demand deposit liabilities of U.S. commercial banks to foreign governments and commercial banks were taken from the Federal Reserve Bulletin table entitled "Assets and Liabilities of Large Commercial Banks," from the columns "Demand Deposits of Foreign Govts., etc." and "Commercial Banks."23 This source was preferable to the data in "Short-Term Liabilities to Foreigners Reported by Banks in the United States, by Type" because the former excludes U.S. commercial bank liabilities to their foreign branches.

Foreign deposits at Federal Reserve Banks were taken from the Federal Reserve Bulletin table entitled

"22These data were computed by averaging end-of-month data for the current and preceding month to make them roughly comparable with daily average data.

23These data were computed by averaging weekly data. For weeks that overlap months, only days that fall in the current month were used. 


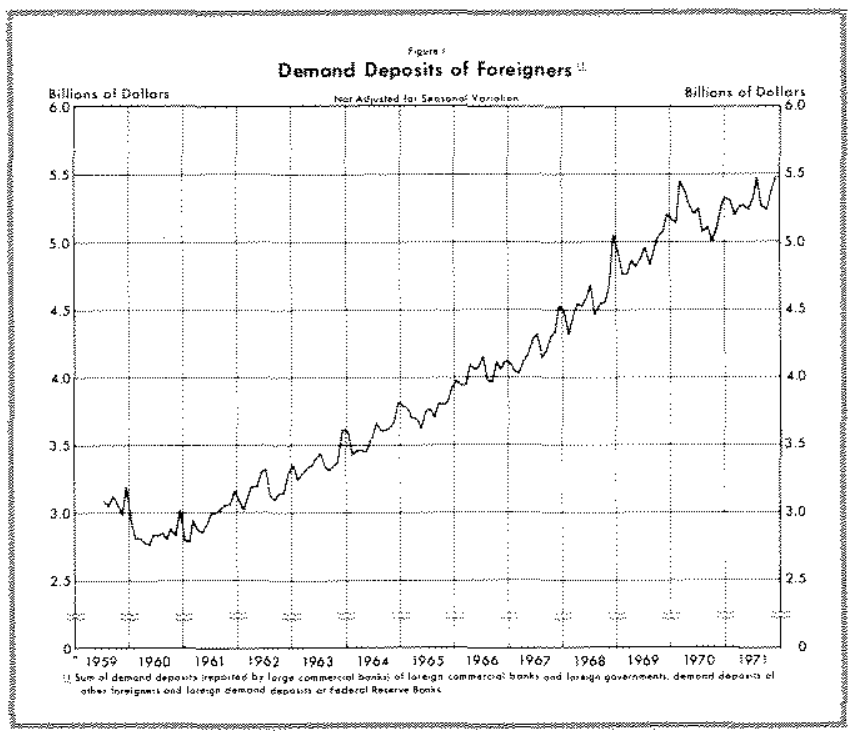

"Member Bank Reserves, Federal Reserve Bank Credit, and Related Items," the column entitled "Deposits, Other Than Member Bank Reserves, With F.R, Banks, Foreign." A small amount of foreign deposits of international institutions at the Federal Reserve reported separately were added to this total.24

The source of foreign time deposits is the Federal Reserve Bulletin table entitled "Short-Term Liabilities to Foreigners Reported by Banks in the United States, by Type," column entitled "To All Foreigners." These data exclude negotiable time certificates of deposit. $^{25}$ The series on foreign time deposits includes liabilities of U.S. banks to their foreign branches and those liabilities of U.S. agencies and branches of foreign banks to their head offices, which are reported as deposits. Hence, the level of foreign time deposits is biased upward by this amount. Beginning in December 1971, the reporting procedure for banks was altered, and these liabilities are now included in "Other Short-Term Liabilities," instead of in time deposits.

Foreign demand deposits at U.S. branches of foreign banks, U.S. agencies of foreign banks and Edge Act corporations are not included in the foreign deposit series. The current measure of demand deposits, which is one of the components used in construction of domestic money stock, reflects changes in domestic demand deposits resulting from transactions involving these foreign deposits. ${ }^{26}$

*These data are avaitable on a daily average basis.

25These data were computed by averaging end-of-month data for the current and preceding month.

"26 An outfow of dollars decreases demand deposits of U.S. residents and increases denand deposits of foreigners at

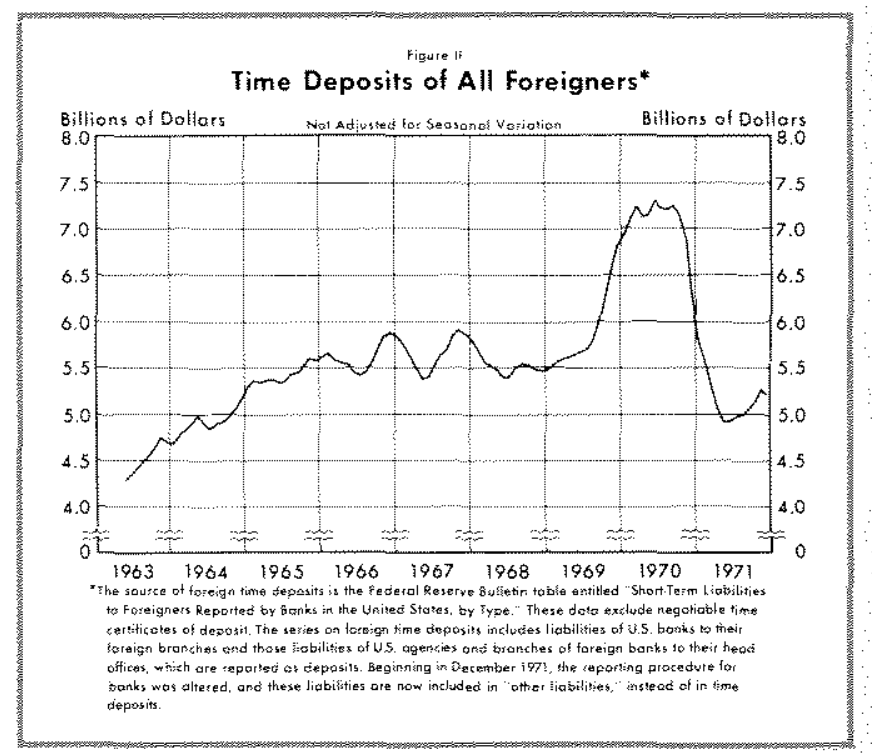

The construction of the monthly series on foreign demand deposits and foreign time deposits is illustrated in Table II and the data are presented in the Appendix. Figures I and II show the movements of the two series, and Figure III compares the growth of domestic demand deposits and foreign demand deposits. ${ }^{2 \pi}$

\section{Consmetion of Domestic Wonen grock Geriess}

Transactions involving foreign deposit accounts generate cash items in process of collection in much the same way as do domestic deposit transactions. Therefore, if foreign deposits are removed from the money stock data, some estimate of the cash items arising from transactions in these accounts must be added back into the money stock data (CIPC, including foreign CIPC, are deducted from gross demand deposits). Unless this adjustment is made, changes in CIPC arising from foreign deposit transactions will

institutions mentioned above. However, cash itens in process of collection associated with these transactions are deducted from gross demand deposits and therefore cause a decrease in the money stock. As long as these foreign demand deposits do not become permanent, thus producing an elimination of CIPC and reserve clearing among U.S. banks, these dollar outllows are accounted for in the current meastre of the money stack. Since most of these deposits are of a temporary nature, and since data on deposits held pernanently by foreigners at U.S. branches and agencies are not available, we assume that the level of these deposits is fairly constant and thus are not included in our series on foreign deposits.

2:Growth rates are computed by comparing the most recent 3 -month average with the 3-month average ended 12 months previously. For example, the growth rate for December 1970 is computed by comparing the average for the 3 months eneted December 1970 with the 3 months ended December 1969. 


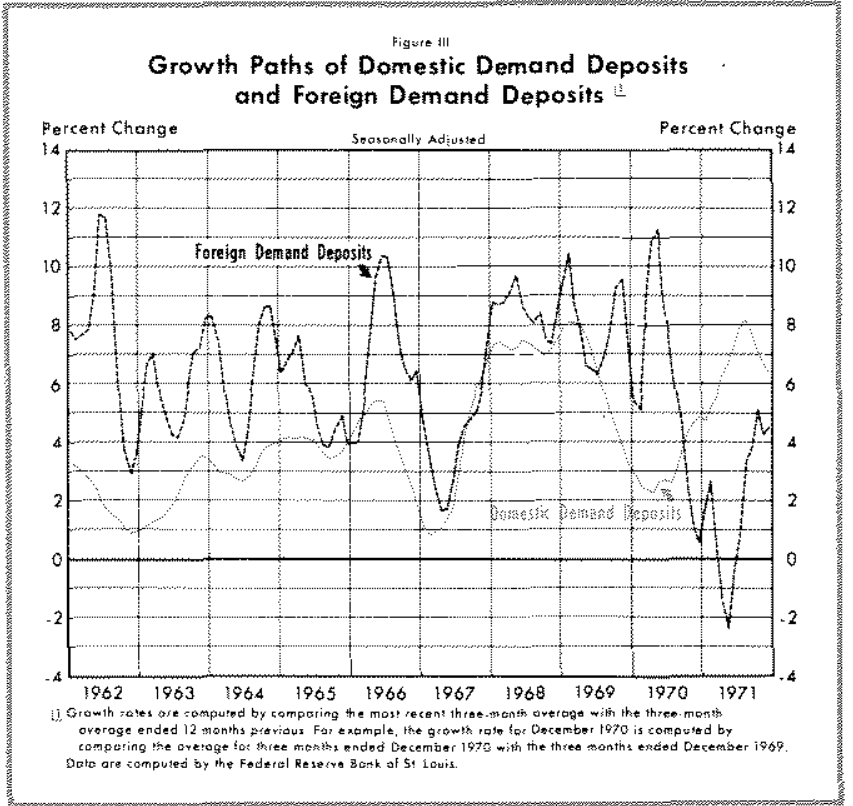

result in biased estimates of the domestic money stock.

Unfortunately, only total CIPC data are reported; no separation is made between CIPC arising from foreign deposit transactions. Consequently, foreign CIPC were estimated as a ratio of total CIPC by the following procedure: ${ }^{28}$

$$
\mathrm{CIPCF}=\left(\frac{\mathrm{DDF}}{\mathrm{DD}}\right)\left(\mathrm{CIPC}_{\mathrm{LCB}}\right)
$$

The monthly estimates of cash items in process of collection generated by foreign deposits included in the money stock data are illustrated in Figure IV and given in the Appendix.

Not seasonally adjusted deposit data and cash items in process of collection were used in constructing the $\mathrm{DM}_{1}$ and $\mathrm{DM}_{2}$ series. To develop the seasonally ad justed money stock series, domestic demand deposits and domestic time deposits were seasonally adjusted

28Demand deposits and cash items in process of collection by large commercial banks are converted to a daily average basis by averaging weekly data. For weeks that overlap months, only days that fall in the current month were inciuded.

CIPCF = Cash items in process of collection arising from transactions in demand deposits due to foreigners

DDF = Demand deposits due to foreigners at commercial banks; demand deposits due to foreigners at Federal Reserve Banks are excluded

DD $\quad=$ Total demand deposits reported by large commercial banks

CIPC = Total cash items in process of collection LCB reported by large commercial banks

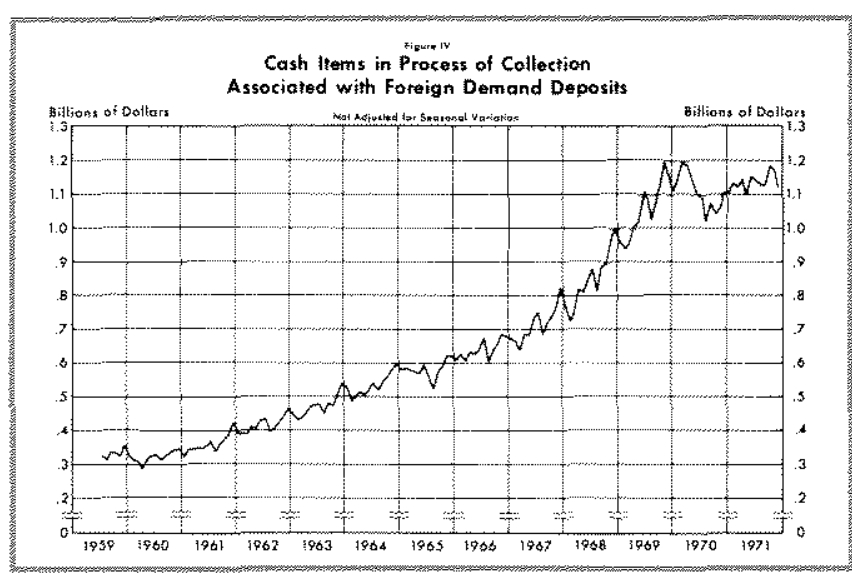

separately using the $\mathrm{X}-11$ seasonal adjustment computer program. ${ }^{29}$ The seasonally adjusted currency component of the money stock was then added to seasonally adjusted domestic demand deposits to compute seasonally adjusted domestic money stock. The seasonally adjusted $\mathrm{DM}_{2}$ series was constructed by adding seasonally adjusted net domestic time deposits to seasonally adjusted domestic $\mathrm{M}_{1}$. The construction of the domestic money stock series is illustrated in Table III, and monthly data for these series are presented in the Appendix to this article.

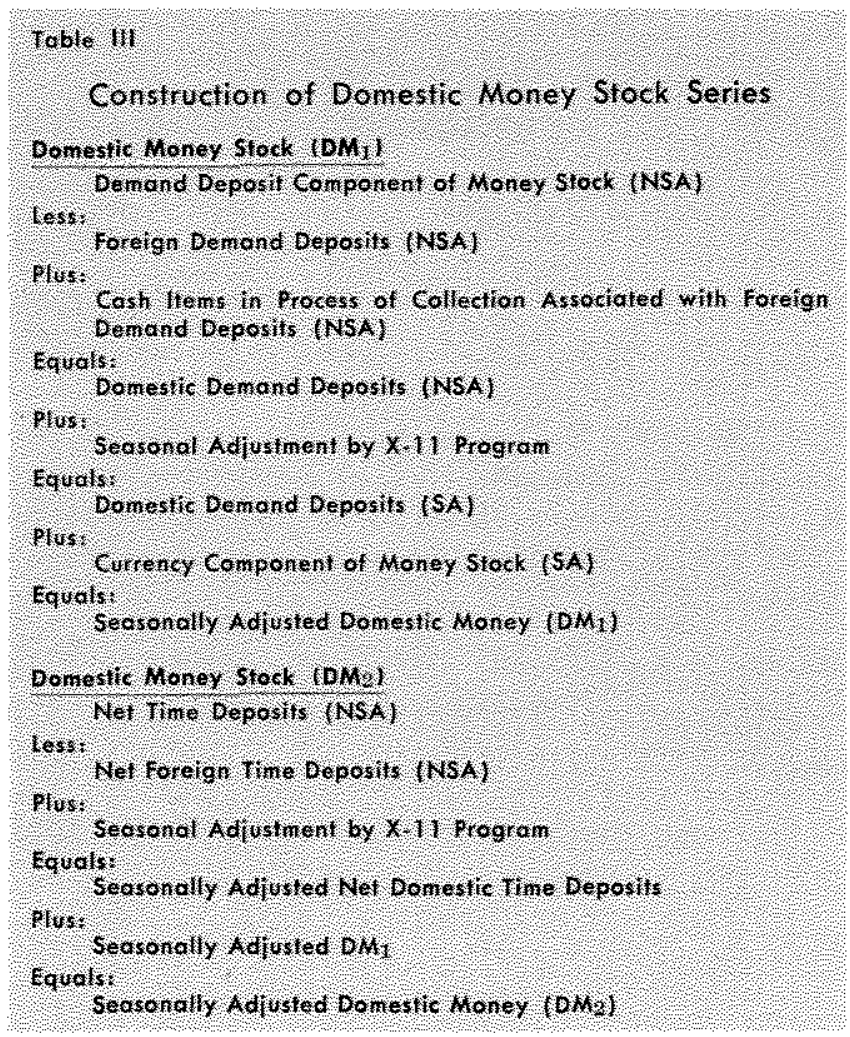

20 This procedure closely approximates the Federal Reserve Board's method of seasonally adjusting the demand deposit component of money. However, in addition to the X-11 program, the Board sometimes uses "informed judgment" to compute seasonal factors. 


\section{Conclusions}

Outflows of dollars do not result in a change in the money stock series as currently defined when foreigners increase their demand deposits at U.S. commercial banks. Although the composition of ownership of demand deposits is changed - U.S. residents hold less and foreigners hold more U.S. demand deposit balances - the money stock remains unchanged. Similarly, in the case where central banks increase their holdings of demand deposits at the Federal Reserve, the current money stock does not reflect the initial effect of this action on domestic demand deposits.

In both domestic money stock series developed in this article, outflows of dollars result in changes in the money stock series in all eases except where the dollars are reinjected directly back into deposits held by U.S. residents. A change in the composition of the ownership of demand deposits affects the growth of domestic money. For example, a decrease in demand deposits of U.S. residents and an increase in demand deposits owned by foreigners at U.S, commercial banks would appear as a decrease in the domestic moncy stock series.

Concern with the growth of money is twofold: (1) changes in the supply and demand for this asset result in predictable portfolio adjustments by economic units, and hence predictable effects on spending, which generates income for U.S. residents and influences prices and employment, and (2) the Federal Reserve can control the growth trend of money. When foreign deposits were included in the U.S. money stock data, the Federal Reserve asserted that these deposits were available for spending, the same as other deposits. However, it may be that foreigners react differently to changes in their holdings of dollars than do U.S. residents. In such a case, it is not only the size of the money stock that is important for stabilization policy, but also the composition of the money stock.

This article and the accompanying Appendix are

available as Reprint No. 77

\begin{abstract}
APPENDIX
In this section the basic data used in constructing the domestic money stock series are presented. The following projected seasonal factors for 1972 are presented for those readers interested in updating the seasonally adjusted domestic demand deposit series. These factors are to be applied to the not seasonally adjusted domestic demand deposit series. This series may be updated by using the data available in the Federal Reserve Bulletin in the tables cited in the text of this article.

January

February

March

April

May

June

103.5

99.0

98.9

100.8

98.0

99.2

July

August

September

October

November

December

99.3

98.3

99.2

99.8

100,6

103.0
\end{abstract}


Basic Data for Construction of Domestic Money Stock Series ${ }^{1}$

(Billions of Dollars)

Unadjusted Domestic

\begin{tabular}{|c|c|c|c|c|c|c|c|}
\hline \multirow[b]{2}{*}{ Date } & \multicolumn{4}{|c|}{$\begin{array}{l}\text { Uradjusted Domestic } \\
\text { Demand Deposits }\end{array}$} & \multicolumn{3}{|c|}{$\begin{array}{c}\text { Seasonally Adjusted Domestic } \\
\text { Money Stoek (OM) }\end{array}$} \\
\hline & $\begin{array}{l}\text { Demand } \\
\text { Deposits: } \\
\text { (NSA) }\end{array}$ & $\begin{array}{l}\text { Foreiga } \\
\text { Demmand } \\
\text { Deposits } \\
\text { (WSA) }\end{array}$ & $\begin{array}{c}\text { Foreign } \\
\text { CIPC } \\
+\quad \text { (NSA) }\end{array}$ & $\begin{aligned} & \text { Dornestic } \\
& \text { Demand } \\
&=\text { Deposits } \\
& \text { (NSA) }\end{aligned}$ & $\begin{array}{l}\text { Dornestic } \\
\text { Demand } \\
\text { Depasits } \\
\text { (SA) }\end{array}$ & $\begin{array}{c}\text { Cu\&rency } \\
\text { (SA) }\end{array}$ & psA \\
\hline $7 / 59$ & 114.000 & 3.095 & 0.328 & 111.233 & 113.015 & 29.000 & 142015 \\
\hline $8 / 59$ & 113.600 & 3.047 & 0.312 & 110.865 & 112.769 & 29.100 & 141869 \\
\hline $9 / 59$ & 114.200 & 3.129 & 0.336 & $\$ 11.407$ & 112.281 & 29.000 & 141281 \\
\hline $10 / 59$ & 114.500 & 3.062 & 0.333 & 111.771 & 111.784 & 29.000 & 140,784 \\
\hline $11 / 59$ & 115.400 & 2.987 & 0.327 & 112.740 & 111.652 & 28.900 & 140552 \\
\hline $12 / 59$ & $\$ 16.800$ & 3.193 & 0.355 & 113,962 & 110.700 & 28.900 & 139600 \\
\hline $1 / 60$ & 116.800 & 2.964 & 0.329 & 114.165 & 110.649 & 29.000 & 139649 \\
\hline $2 / 60$ & 113.300 & 2.816 & 0.315 & 110.799 & 110.353 & 29.000 & 139353 \\
\hline $3 / 60$ & 111.700 & 2.812 & 0.306 & 109.194 & 110.005 & 29.000 & 139005 \\
\hline $4 / 60$ & 112.600 & 2.773 & 0.286 & 110.113 & 109.566 & 29.000 & 138.566 \\
\hline $5 / 60$ & 110.300 & 2.764 & 0.315 & 107.851 & 109.700 & 29.000 & 138700 \\
\hline $6 / 60$ & 110.400 & 2.840 & 0.327 & 107.887 & 109.745 & 29.000 & 138745 \\
\hline $7 / 60$ & 110.600 & 2.831 & 0.328 & 108.097 & 109.760 & 29.000 & 138760 \\
\hline $8 / 60$ & 111.200 & 2.852 & 0.312 & 108.660 & 110.516 & 29.000 & 539516 \\
\hline $9 / 60$ & 112.100 & 2.802 & 0.325 & 109.623 & 110.481 & 29.000 & 139.481 \\
\hline $10 / 60$ & 112.900 & 2.881 & 0.335 & 10.354 & 110.315 & 29.000 & 139315 \\
\hline $11 / 60$ & 113.600 & 2.830 & 0.344 & 111.114 & 110.021 & 29.000 & 1390021 \\
\hline $12 / 60$ & 115.900 & 3.022 & 0.346 & 113.224 & 109.960 & 28.900 & 138.860 \\
\hline $1 / 61$ & 116.400 & 2.794 & 0.326 & 113.932 & 110.367 & 29.000 & 139367 \\
\hline $2 / 61$ & 113.800 & 2.791 & 0.344 & 111.353 & 110.918 & 28.900 & 139.818 \\
\hline $3 / 61$ & 113.000 & 2.947 & 0.345 & 110.398 & 111.227 & 00 & 140127 \\
\hline $4 / 61$ & 114.600 & 2.871 & 0.351 & 112.080 & 111.509 & 29.000 & 140.509 \\
\hline $5 / 61$ & 112.900 & 2.857 & 0.348 & 110 & 112.329 & & 141229 \\
\hline $6 / 61$ & 113.200 & 2.911 & 0.355 & 110.644 & 112.544 & 28.900 & 141,444 \\
\hline $7 / 61$ & 113.200 & 2.989 & 0.369 & 110.580 & 112.261 & 29.000 & 261 \\
\hline $8 / 61$ & 113.200 & 2.993 & 0.339 & 110.546 & 112.511 & 00 & 141611 \\
\hline $9 / 61$ & 114.600 & 3.021 & 0.360 & 111.939 & 112.853 & 29.200 & 142053 \\
\hline $10 / 61$ & 800 & 3.052 & 0.374 & 113.122 & 113.029 & 29.300 & 142329 \\
\hline $11 / 61$ & 117.300 & 3.061 & 0.390 & $\$ 14.629$ & 113.504 & 29.400 & 142904 \\
\hline $12 / 61$ & 120.000 & 3.164 & 0.423 & 117.259 & & 29.600 & 143445 \\
\hline $1 / 62$ & 120.200 & 3,087 & 0.392 & 505 & 113.708 & 29.600 & 143300 \\
\hline $2 / 62$ & 117.100 & 3.014 & 0.390 & 114.476 & 114.067 & 29.700 & 143,767 \\
\hline $3 / 62$ & $\$ 16.100$ & 3.113 & 0.389 & 113.376 & 114.206 & 29.800 & 144006 \\
\hline $4 / 62$ & 117.800 & 3.190 & 0.410 & 115.020 & $\$ 14.314$ & 30.000 & 144314 \\
\hline $5 / 62$ & 115.200 & 3.182 & & & 114.406 & 30.000 & 144,406 \\
\hline $6 / 62$ & 115.200 & 3.295 & 0.430 & 112.335 & 114.149 & 30.100 & 144249 \\
\hline $7 / 62$ & 115.200 & 3.315 & 0.433 & 112.318 & 114.085 & 30.100 & 144185 \\
\hline $8 / 62$ & 114.500 & 3.137 & 0.397 & 111.760 & 113.947 & 30.200 & 144,147 \\
\hline $9 / 62$ & 115.400 & 3.092 & 0.404 & 112.712 & 113.728 & 30.300 & 144028 \\
\hline $10 / 62$ & 116.900 & 3.146 & 0.424 & 114.178 & 114.054 & 30.300 & 144354 \\
\hline $11 / 62$ & 118.200 & 3.141 & 0.439 & 115.498 & 114.402 & 30.400 & 144802 \\
\hline $12 / 62$ & 121.100 & 3,286 & 0.461 & 118.275 & 114.780 & 30.600 & 145380 \\
\hline $1 / 63$ & 122.000 & 3.352 & 0.448 & 119.096 & & 30.700 & 145806 \\
\hline $2 / 63$ & 118.600 & 3.248 & 0.432 & 115.784 & 115.524 & 30.900 & 146424 \\
\hline $3 / 63$ & 117.600 & 3.283 & 0.435 & 114.752 & 115.659 & 31.000 & 146659 \\
\hline $4 / 63$ & 119.600 & 3.330 & 0.454 & 116.724 & 115.969 & 31.100 & 147069 \\
\hline $5 / 63$ & 117.200 & 3.350 & 0.473 & 114.323 & 116.530 & 31.300 & 147830 \\
\hline $6 / 63$ & 117.600 & 3.408 & 0.475 & 114.667 & 116.507 & 31.500 & 148007 \\
\hline $7 / 63$ & 118.400 & 3.445 & 0.477 & 115.432 & 117.126 & 31.600 & 148726 \\
\hline $8 / 63$ & 118.000 & 3.347 & 0.449 & 115.102 & 117.438 & 31.800 & 14923 \\
\hline $9 / 63$ & 119.300 & 3.315 & 0.479 & 116.464 & 117.483 & 31.900 & 14938 \\
\hline
\end{tabular}

Seasenaly Adjusted Domestic

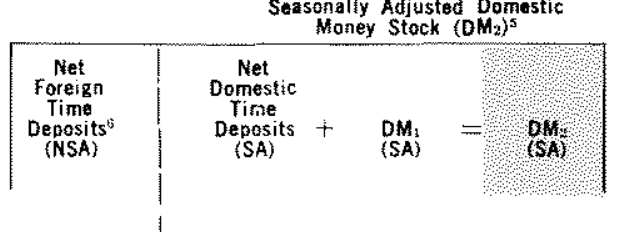




\begin{tabular}{|c|c|c|c|c|c|c|c|c|c|c|c|}
\hline \multirow[b]{2}{*}{ Date } & \multicolumn{4}{|c|}{$\begin{array}{c}\text { Unadjusted Domestic } \\
\text { Demand Deposits }\end{array}$} & \multicolumn{3}{|c|}{$\begin{array}{l}\text { Seasonally Adtusted Domestic } \\
\text { Money Stock (DMin) }\end{array}$} & \multicolumn{4}{|c|}{$\begin{array}{l}\text { Seasonalyy Adiusted Domestic } \\
\text { Money Stock }\left(\mathrm{DM}_{2}\right)^{\mathrm{x}}\end{array}$} \\
\hline & $\begin{array}{l}\text { Demand } \\
\text { Deposits: } \\
\text { (NSA) }\end{array}$ & $\begin{array}{l}\text { Foreign } \\
\text { Demand } \\
\text { Deposits } \\
\text { (NSA) }\end{array}$ & $\begin{array}{l}\text { Foregn } \\
\text { CEPCA } \\
+\quad(N S A)\end{array}$ & $\begin{aligned} & \text { Domestic } \\
& \text { Dermand } \\
&= \\
&=\text { Deposits } \\
& \text { (NSA) }\end{aligned}$ & $\begin{array}{l}\text { Domestic } \\
\text { Demand } \\
\text { Demasits } \\
\text { (SA) }\end{array}$ & $\begin{array}{l}\text { Carrency } \\
(S A)\end{array}$ & $\sqrt{\mathrm{onh}} \mathrm{SH}$ & $\begin{array}{c}\text { Net } \\
\text { Foreigh } \\
\text { Finge } \\
\text { Dtonsits } \\
\text { (NSA) }\end{array}$ & $\begin{array}{l}\text { Net } \\
\text { Domestic } \\
\text { Ineme } \\
\text { Deposits tw } \\
\text { (SA) }\end{array}$ & $\begin{array}{l}\mathrm{DM}_{1} \\
(\mathrm{SA})\end{array}$ & byst. \\
\hline $10 / 63$ & 121.000 & 3.346 & 0.474 & 118.128 & 137.884 & 32.000 & 149884 & 4.651 & 96.336 & 149.884 & 246220 \\
\hline $11 / 63$ & 122.800 & 3.377 & 0.506 & 119.929 & 118.810 & 32.300 & 151.110 & 4.755 & 97.187 & 151.110 & 248.297 \\
\hline $12 / 63$ & 124.800 & 3.618 & 0.539 & 121.721 & 118.044 & 32.500 & 150544 & 4.699 & 98.015 & 150.544 & 248559 \\
\hline $1 / 64$ & 125.900 & 3.597 & 0.523 & 122.826 & 118.559 & 32.600 & $351 / 159$ & 4.688 & 98.258 & $151 . \$ 59$ & 249417 \\
\hline $2 / 64$ & 122.000 & 3.429 & 0.485 & 119.056 & 119.007 & 32.800 & 151807 & 4.786 & 98.964 & 151.807 & 250771 \\
\hline $3 / 64$ & 120.900 & 3,465 & 0.498 & 117.933 & 118.932 & 32.900 & 151832 & 4.829 & 99.391 & 151.832 & 251228 \\
\hline $4 / 64$ & 122.900 & 3.455 & 0.513 & 119.958 & 119.103 & 33.100 & 152203 & 4.898 & 100.087 & 152.203 & 252290 \\
\hline $5 / 64$ & 120.000 & 3.45 & 0.503 & $\$ 17.052$ & 119.487 & 33.300 & 152787 & 4.977 & 100.912 & 152.787 & 253699 \\
\hline $6 / 64$ & 120.800 & 3.533 & 0.519 & 117.786 & 119.570 & 33.500 & 153070 & 4.891 & 102.033 & 153.070 & 256103 \\
\hline $7 / 64$ & 122.300 & 3.666 & 0.540 & 119.174 & 120.820 & 33.600 & 754.420 & 4.842 & 102.731 & 154.420 & 257.151 \\
\hline $8 / 64$ & 122.100 & 3.610 & 0.519 & 119.009 & 121.492 & 33.800 & 155292 & 4.893 & 103.582 & 155.292 & 258874 \\
\hline $9 / 64$ & 124.200 & 3.605 & 0.542 & 121,137 & 122.163 & 33.900 & 156063 & 4.918 & 104.710 & 156.063 & 260773 \\
\hline $10 / 64$ & 126.000 & 3.630 & 0.560 & 122.930 & 122.601 & 34.000 & 156.601 & 4.991 & 105.666 & 156.601 & $26 ? 267$ \\
\hline $11 / 64$ & 127.300 & 3.662 & 0.576 & 124.214 & 123.101 & 34.200 & 157,301 & 5.069 & 106.749 & 157.301 & 264050 \\
\hline $12 / 64$ & 130.300 & 3.818 & 0.600 & 127.082 & 123.184 & 34.200 & 157.804 & 5.167 & 108.041 & 157.384 & 265425 \\
\hline $1 / 65$ & 131.300 & 3.788 & 0.581 & 128.093 & 123.528 & 34.400 & 157928 & 5.295 & 109.617 & 157.928 & 267545 \\
\hline $2 / 65$ & 126.500 & 3.770 & 0.586 & 123.316 & 123.534 & 34.600 & 756434 & 5.345 & 111.428 & 158.134 & 269562 \\
\hline $3 / 65$ & 125.900 & 3.697 & 0.580 & 122.783 & 123.903 & 34.700 & 158608 & 5.338 & 112.327 & 158.603 & 270980 \\
\hline $4 / 65$ & 128.400 & 3.695 & 0.574 & 125.279 & 124.353 & 34.700 & 159053 & 5.350 & 113.478 & 159.053 & 272531 \\
\hline $5 / 65$ & 124.200 & 3.619 & 0.571 & 121.152 & 123.835 & 34.900 & 158735 & 5.350 & 114.342 & 158.735 & 270.077 \\
\hline $6 / 65$ & 125.900 & 3.748 & 0.595 & 122.747 & 124.430 & 35.000 & 159.430 & 5.327 & 115.465 & 159.430 & 274695 \\
\hline $7 / 65$ & 126.700 & 3.768 & 0.560 & 123.492 & 125.065 & 35.200 & 160265 & 5.353 & 116.900 & 160.265 & 277165 \\
\hline $8 / 65$ & 126.000 & 3.704 & 0.522 & 122.818 & 125.365 & 35.500 & 160.865 & 5.428 & 118.221 & 160.865 & 279086 \\
\hline $9 / 65$ & 128.600 & 3.809 & 0.573 & 125.364 & $\$ 26.355$ & 35.700 & 162055 & 5.446 & 119.650 & 162.055 & $28 \% 705$ \\
\hline $10 / 65$ & 130.800 & 3.797 & 0.592 & 127.595 & 127.244 & 36.000 & 168244 & 5.510 & 121.323 & 163.244 & 284567 \\
\hline $11 / 65$ & 131.900 & 3.821 & 0.623 & 128.702 & 127.607 & 36.100 & 160.707 & 5.585 & 122.962 & 163.707 & 286669 \\
\hline $12 / 65$ & 136.000 & 3.924 & 0.623 & 132.699 & 128.597 & 36.300 & 164.897 & 5.562 & 124.443 & 164.897 & 289340 \\
\hline $1 / 66$ & 137,600 & 3.978 & 0.609 & 134.231 & 129.400 & 36.600 & 166,000 & 5.614 & 125.658 & 166.000 & 291,658 \\
\hline $2 / 66$ & 132.500 & 3.944 & 0.627 & 29.183 & 129.712 & 36.700 & 166,412 & 5.649 & 126.513 & 166.412 & 292925 \\
\hline $3 / 66$ & 132.400 & 3.944 & 0.605 & 29.061 & 130.323 & 36.900 & 167223 & 5.577 & 127.047 & 167.223 & 294270 \\
\hline $4 / 66$ & 135.800 & 4.088 & 0.634 & 132.346 & 131.328 & 37.100 & 168428 & 5.557 & 128.649 & 168.428 & 297077 \\
\hline $5 / 66$ & 131.000 & 4.051 & 0.628 & 127.577 & 130.510 & 37,300 & 167810 & 5.538 & 130.410 & 167.810 & 298220 \\
\hline $6 / 66$ & 132.700 & 4.078 & 0.641 & 129.263 & 130.840 & 37.400 & 168240 & 5.449 & 130.997 & 168.240 & 299237 \\
\hline $7 / 66$ & 131.500 & 4.154 & 0.676 & 128.022 & 129.466 & 37.600 & 167066 & 5.428 & 132.375 & 167.066 & 299444 \\
\hline $8 / 66$ & 130.500 & 3.974 & 0.603 & 127.129 & 129.695 & 37.800 & 167,495 & 5.456 & 133.433 & 167.495 & 300.928 \\
\hline $9 / 66$ & 133.100 & 3.963 & 0.637 & 129.774 & 130.739 & 37.900 & 168639 & 5.559 & 134.371 & 168.639 & 300.010 \\
\hline $10 / 66$ & 133.600 & 4.116 & 0.657 & 130.141 & 129.830 & 38.000 & 167830 & 5.734 & 135.124 & 167.830 & 302954 \\
\hline $11 / 66$ & 134,100 & 4.05 & 0.685 & 130.734 & 129.690 & 38.200 & 167890 & 5.848 & 135.597 & 167.890 & 303467 \\
\hline $12 / 66$ & 137.800 & 4.117 & 0.680 & 134.363 & 130.225 & 38.300 & 168525 & 5.879 & 136.489 & 168.525 & 305014 \\
\hline $1 / 67$ & 137.900 & 4.102 & 0.674 & 134.472 & 129.652 & 38.500 & 168152 & 5.837 & 138.192 & 168.152 & 306.344 \\
\hline $2 / 67$ & 133,400 & 4.043 & 0.666 & 130.023 & 130.826 & 38.700 & 169526 & 5.753 & 140.042 & 169.526 & 309568 \\
\hline $3 / 67$ & 134.600 & 4.030 & 0.639 & 131.209 & 132.559 & 38.900 & 171459 & 5.615 & 141.433 & 171.459 & 312892 \\
\hline $4 / 67$ & 136.300 & 4.116 & 0.686 & 132.870 & 131.829 & 39.000 & 170829 & 5.477 & 143.944 & 170.829 & 314.773 \\
\hline $5 / 67$ & 133.500 & 4.165 & 0.685 & 130.020 & 133.004 & 39.100 & 172104 & 5.384 & 146.069 & 172.104 & 318173 \\
\hline $6 / 67$ & 136.500 & 4.276 & 0.729 & 132.953 & 134.359 & 39,300 & 170659 & 5.398 & 148.247 & 173.659 & 321906 \\
\hline $7 / 67$ & 137.600 & 4.315 & 0.751 & 134.036 & 135.370 & 39.400 & 174770 & 5.541 & 150.003 & 174.770 & 324773 \\
\hline $8 / 67$ & 137.700 & 4.148 & 0.688 & 134.240 & 136.843 & 39.500 & 176343 & 5.642 & 151.595 & 176.343 & 327938 \\
\hline $9 / 67$ & 140.000 & 4. 191 & 0.719 & 136.528 & 137.496 & 39.700 & 37196 & 5.705 & 153.125 & 177.196 & 330,321 \\
\hline $10 / 67$ & 142.000 & 4.295 & 0.740 & 138.445 & 138.230 & 39.900 & 178130 & 5.852 & 154.566 & 178.130 & 332696 \\
\hline $11 / 67$ & 143.400 & 4.334 & 0.763 & 139.829 & 138.791 & 40.000 & 178791 & 5.929 & 155.785 & 178.791 & 334576 \\
\hline $12 / 67$ & 147.400 & 4.536 & 0.824 & 143.688 & 139.300 & 40.400 & 179,200 & 5.863 & 156.795 & 179.700 & 336495 \\
\hline $1 / 68$ & 148.800 & 4.492 & 0.767 & 145.075 & 139.963 & 40.600 & 180,563 & 5.776 & 158.063 & 180.563 & 338626 \\
\hline $2 / 68$ & 143.000 & 4.313 & 0.725 & 139.412 & 140.514 & 40.700 & 181214 & 5.692 & 159.708 & 181.214 & 340.922 \\
\hline $3 / 68$ & 143.400 & 4.459 & 0.752 & 139.693 & $\$ 41.167$ & 41.100 & 182.267 & 5.569 & 160.835 & 182.267 & 343102 \\
\hline
\end{tabular}




\begin{tabular}{|c|c|c|c|c|c|c|c|c|c|c|c|}
\hline \multirow[b]{2}{*}{ Date } & \multicolumn{4}{|c|}{$\begin{array}{l}\text { Unadiusted Darnestic } \\
\text { Demand De posits }\end{array}$} & \multicolumn{3}{|c|}{$\begin{array}{l}\text { Seasonatlly Adjusted Domestic } \\
\text { Money Stock (DM) }\end{array}$} & \multicolumn{4}{|c|}{$\begin{array}{l}\text { Seasonally Adjusted Domestic } \\
\text { Money Stock }\left(0 M_{2}\right)^{*}\end{array}$} \\
\hline & $\begin{array}{c}\text { Demand } \\
\text { Deponsits? } \\
\text { (NSA) }\end{array}$ & $\begin{array}{l}\text { Foreign } \\
\text { Demanand } \\
\text { Deposists } \\
\text { (NSA) }\end{array}$ & 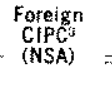 & $\begin{array}{l}\text { Domestic } \\
\text { Demantid } \\
= \\
= \\
\text { Defositits } \\
\text { (NSA }\end{array}$ & $\begin{array}{l}\text { Damestre } \\
\text { Demand } \\
\text { Depositis } \\
\text { (ISA) }\end{array}$ & $\begin{array}{c}\text { Curreneyt } \\
(S A)^{2}\end{array}$ & BSA & $\begin{array}{l}\text { Net } \\
\text { Foreign } \\
\text { Time } \\
\text { Degositis } \\
\text { (NSA) }\end{array}$ & $\begin{array}{c}\text { Net } \\
\text { Domestic } \\
\text { Tirme } \\
\text { Deposits } \\
\text { (SA) }\end{array}$ & $\begin{array}{l}\mathrm{OMA}_{3} \\
(\mathrm{SA})\end{array}$ & (5A) \\
\hline $4 / 68$ & 146.600 & 4.548 & 0.819 & 142.871 & 141.726 & 41.300 & 183.026 & 5.514 & 161.880 & 183.026 & 344.906 \\
\hline $5 / 68$ & 143.700 & 4.526 & 0.811 & 139.985 & 143.100 & 41.600 & 184,700 & 5.485 & 162.752 & 184.700 & 347.452 \\
\hline $6 / 68$ & 146.600 & 4.595 & 0.844 & 142.849 & 144.181 & 41.900 & $186.08 \%$ & 5.394 & 163.880 & 186.081 & 349.961 \\
\hline $7 / 68$ & 147.800 & 4.686 & 0.882 & 143.996 & 145.249 & 42.000 & 87249 & 5.414 & 165.003 & 187.249 & 352.252 \\
\hline $8 / 68$ & 147.300 & 4.462 & 0.812 & 143.650 & 146.316 & 42.300 & 188.616 & 5.495 & 167.077 & 188.616 & 355.693 \\
\hline $9 / 68$ & 149.600 & 4.546 & 0.887 & 145.941 & 147.007 & 42.700 & 189.707 & 5.536 & 169.134 & 189.707 & 358.84 \\
\hline $10 / 68$ & 151.500 & 4.555 & 0.893 & 147.838 & 147.819 & 42.800 & $190.6+9$ & 5.523 & 171.287 & 190.619 & 361.906 \\
\hline $11 / 68$ & 154.100 & 4.650 & 0.966 & 150.416 & $\$ 49.423$ & 43.200 & 192623 & 5.478 & 173.429 & 192.623 & 366.052 \\
\hline $12 / 68$ & 159.100 & 5.058 & 1.002 & 155.044 & 150.440 & 43.400 & 193.840 & 5.472 & 175.394 & 193.840 & 369.234 \\
\hline $1 / 69$ & 160.700 & 4.930 & 0.958 & 156.728 & 151.234 & 43.600 & 194.834 & 5.487 & 176.583 & 194.834 & 37.417 \\
\hline $2 / 69$ & 154.400 & 4.760 & 0.940 & 150.580 & 151.873 & 43.900 & 195.773 & 5.529 & 177.180 & 195.773 & 372953 \\
\hline $3 / 69$ & 154.600 & 4.764 & 0.954 & 150.790 & 152.342 & 44.100 & 196.442 & 5.58 & 177.629 & 196.442 & 374.071 \\
\hline $4 / 69$ & 158.200 & 4.866 & 1.004 & 154 & 153.079 & 44.200 & 197.279 & 5.6 & 178.122 & 197.279 & 375.401 \\
\hline $5 / 69$ & 153.500 & 4.820 & 1.017 & 149. & 152.854 & 44.500 & 197.354 & 5 . & $178.37 \dagger$ & 197.354 & 375,725 \\
\hline $6 / 69$ & 155.800 & 4.877 & 1.080 & 15 & 153.275 & 44.700 & 197975 & 5.664 & 179.528 & 197.975 & 377.503 \\
\hline $7 / 69$ & 156.400 & 4.963 & 1.111 & & 153.731 & 44.900 & 198.631 & 5.6 & 178.298 & 198.631 & 76.929 \\
\hline $8 / 69$ & 154.300 & 4.830 & 1.026 & 150.496 & 153.132 & 45.200 & 198332 & 5.767 & 177.193 & 198.332 & 375525 \\
\hline $9 / 69$ & 156.100 & 4.949 & 1.081 & 15 & .285 & 45.300 & 198 & 5. & .145 & 198.585 & 375730 \\
\hline $10 / 69$ & 157.600 & 5.038 & 1.119 & 15 & 153.760 & 45.600 & 199360 & 6.2 & 176.742 & 199.360 & 376.102 \\
\hline $11 / 69$ & 158.900 & 5.073 & 1.196 & 15 & 153.928 & 45.900 & 199.828 & 6 & 176.702 & 199.828 & 376.530 \\
\hline $12 / 69$ & 162.900 & 5.207 & 1.153 & 158 & 154.024 & 46.000 & 200 & 6 & 176.323 & 200.024 & 376347 \\
\hline $1 / 70$ & 165.400 & 5.159 & 1.110 & 16 & 155.927 & 46.200 & 202.127 & 6.9 & 176.181 & 202.127 & 378308 \\
\hline $2 / 70$ & 156.800 & 5.141 & 1.142 & 152. & 154.335 & 46.400 & 200.735 & 7.1 & 5.631 & 200.735 & 376.366 \\
\hline $3 / 70$ & 158.400 & 5.450 & 1.196 & 154 & 155.806 & 46.700 & 202506 & 7.24 & 176.394 & 202.506 & 378.900 \\
\hline $4 / 70$ & 162.600 & 5.379 & 1.191 & & 164 & 47.100 & 204 & 7. & 140 & 204.264 & 382404 \\
\hline $5 / 70$ & 158.000 & 5.267 & 1.156 & 153 & 157.051 & 47.600 & 204.651 & 7.1 & 179.491 & 204.651 & 384142 \\
\hline $6 / 70$ & 160.100 & 5.203 & 1.107 & 156.004 & 157.255 & 47.700 & 204955 & 7.2 & 181.492 & 204.955 & 386.447 \\
\hline $7 / 70$ & 160.700 & 5.251 & 1.097 & 156.546 & 157.650 & 48.000 & 205650 & 7.2 & 184.027 & 205.650 & 389.677 \\
\hline $8 / 70$ & 160.400 & 5.070 & 1.021 & & .034 & 48.100 & 207.134 & 7.2 & 186.997 & 207.134 & 394.131 \\
\hline $9 / 70$ & 163.200 & 5.110 & 1.073 & 159 & 160.295 & 48.300 & 208.595 & 7.249 & 189.509 & 208.595 & 398.104 \\
\hline $10 / 70$ & 164.600 & 5.004 & 1.041 & 160.637 & 160.859 & 48.500 & 209.359 & 7.154 & 191.983 & 209.359 & 401342 \\
\hline $11 / 70$ & 166.300 & 5.100 & 1.063 & & 161.151 & 48.700 & & 6.882 & .980 & & 403.831 \\
\hline $12 / 70$ & 171.300 & 5.291 & 1.103 & 16 & 162.060 & 49.000 & & 6 & 992 & 211.060 & 408052 \\
\hline $1 / 71$ & 172.300 & 5.328 & 1.103 & 168 & 162.455 & 49.300 & 211.755 & 5.808 & 202.266 & 211.755 & 414021 \\
\hline $2 / 71$ & 166.500 & 5.304 & 1.133 & 162.329 & 163.997 & 49.700 & 213.697 & 5.574 & 207.161 & 213.697 & 420.858 \\
\hline $3 / 71$ & 168.000 & 5.190 & 1.120 & 163.930 & 165.680 & 50.000 & & & 211.971 & 215.680 & 427.651 \\
\hline $4 / 71$ & 172.300 & 5.257 & 1.145 & & 166.837 & 50.500 & 217.337 & 5.056 & 214.806 & 217.337 & 432.143 \\
\hline $5 / 71$ & 169.400 & 5.271 & 1.099 & 165.228 & 168.556 & 50.800 & 219.356 & 4.927 & 217.025 & 219.356 & 436.381 \\
\hline $6 / 71$ & 172.700 & 5.241 & 1.153 & 168.612 & 169.931 & 51.100 & 221031 & 4.935 & 219.948 & 221.031 & 440.979 \\
\hline $7 / 71$ & 174.100 & 5.312 & 1.138 & 169.926 & 171.093 & 51.600 & 222693 & 4.963 & 220.742 & 222.693 & 443.435 \\
\hline $8 / 7 \dagger$ & 173.000 & 5.472 & 1.127 & 168.655 & 171.589 & 51.700 & 223.289 & 4.992 & 221.865 & 223.289 & 445,154 \\
\hline $9 / 71$ & 174.300 & 5.254 & 1.126 & 170.172 & 171.438 & 51.900 & 223.338 & 5.050 & 223.474 & 223.338 & 446812 \\
\hline $10 / 71$ & 175.300 & 5.235 & 1.183 & 171.248 & 171.594 & 52.200 & 223.794 & 5.136 & 225.924 & 223.794 & 449718 \\
\hline $11 / 71$ & 176.900 & 5.373 & 1.172 & 172.699 & 171.616 & 52.200 & 223.816 & 5.265 & 228.252 & 223.816 & 452068 \\
\hline & 181.500 & 5.473 & 18 & 1 & 171.819 & 0 & 224.319 & 5.202 & 231.151 & 224.319 & 455 \\
\hline
\end{tabular}

'Data are based on revisions through the February 1972 Federal Reserve Bulletin.

"Demand deposit series published in the Federal Reserve Bulletin table entitled "Components of Money Stock Measures and Related Iterns."

${ }^{3}$ Cash items in process of collection associated with foreign demand deposits.

"Currency series published in the Federal Reserve Bulletin table entitled "Components of Money Stock Measures and Related Items." 5Prior to 1963 foreign demand and time deposits are not reported separately in the data source used to construct the time deposit series.

6The source of foreign time deposits is the Federal Reserve Bulletin table entitled "Short-Term Liabilities to Foreigners Reported by Banks in the United States, by Type." These data exclude negotiable time certificates of deposit. "The series on foreign time deposits includes liabilities of U.S. banks to their foreign branches and those liabilities of U.S. agencies and branches of foreign banks to their head offices, which are reported as deposits. Beginning December 1971, the reporting procedure for banks was altered, and these liabilities are now included in "Other Liabilities," instead of in time deposits. 